\title{
DETERMINATION OF SOLUBLE ICAM-1 AND TNF $\alpha R$ IN THE CEREBROSPINAL FLUID AND SERUM LEVELS IN A POPULATION OF BRAZILIAN PATIENTS WITH RELAPSING-REMITTING MULTIPLE SCLEROSIS
}

\author{
Soniza Vieira Alves-Leon ${ }^{1,2}$, Elizabeth Batista ${ }^{1,3}$, \\ Regina Papais-Alvarenga', Thereza Quírico-Santos ${ }^{4}$
}

\begin{abstract}
Cytokines and adhesion molecules have been implicated in the pathogenesis of multiple sclerosis (MS), a chronic inflammatory disease of the central nervous system. In this study we analyzed intrathecal (CSF) and serum levels of soluble intercellular adhesion molecule (ICAM-1) and TNF $\alpha R$ (60kD) from 20 patients with clinically definite MS during acute relapse or stable disease. Comparing to control groups of healthy individuals and patients with intervertebral herniated disc, MS patients showed increased levels $(p<0.001)$ of sICAM-1 and TNF $\alpha$ R in both serum and CSF samples. Regardless stage of disease there was no significant difference in the levels of sICAM-1 during acute relapse $(657 \pm 124.9 \mathrm{ng} / \mathrm{ml})$ or remission $(627 \pm 36.2 \mathrm{ng} / \mathrm{ml})$. A steady increase of TNF $\alpha R(60 \mathrm{kD})$ in both serum and CSF, indicate the existence of a continuous inflammatory process within the brain tissue of MS patients despite absence of clinical signs of disease activity.
\end{abstract}

KEY WORDS: multiple sclerosis, cytokines, soluble receptor of tumor necrosis factor (TNF $\alpha$ R), intercellular adhesion molecule ICAM-1.

\begin{abstract}
Determinação dos níveis de ICAM-1 e TNF $\alpha$ R solúvel no líquido cefalorraqueano e soro numa população de pacientes brasileiros com esclerose múltipla forma surto-remissão

RESUMO - Citocinas e moléculas de adesão estão implicadas na patogênese da esclerose múltipla (EM), uma doença inflamatória crônica do sistema nervoso central. Neste estudo, nós determinamos os níveis solúveis da molécula de adesão intercelular (sICAM-1) e TNF $\alpha R(60 \mathrm{kD})$ no soro e líquido cefalorraqueano (LCR) de 20 pacientes com EM clinicamente definida durante surto ou remissão. Os pacientes com EM apresentaram, em comparação com os grupos controle formados por indivíduos sadios e com hérnia de disco intervertebral submetidos a mielografia, níveis significativamente $(p<0.001)$ elevados de sICAM-1 e TNF $\alpha$ R tanto no soro como no LCR. Independente do estágio da doença, nenhuma diferença significativa foi encontrada entre os pacientes durante o surto $(657 \pm 124.9 \mathrm{ng} / \mathrm{ml})$ ou na remissão $(627 \pm 36.2 \mathrm{ng} / \mathrm{ml})$. Um aumento consistente dos níveis de TNF $\alpha$ R no soro e LCR, apontam para a existência de processo inflamatório continuado no tecido cerebral dos pacientes com EM, a despeito da ausência de sinais clínicos de doença em atividade.
\end{abstract}

PALAVRAS-CHAVE: esclerose múltipla, citocinas, receptor solúvel do fator de necrose tumoral (TNF $\alpha$ R), molécula de adesão intercelular ICAM-1.

Multiple sclerosis (MS) is an inflammatory demyelinating disease of the human central nervous system (CNS) of unknown etiology but with genetic and environmental influences ${ }^{1}$. MS is postulated to be a $T$ cell mediated autoimmune disorder resultant from aberrant immune responses to self-antigens leading to myelin destruction ${ }^{2,3}$. Characteris- tic histological features of the disease include perivenular leukocyte infiltration with multifocal inflammation accompanied by primary demyelination with relative but not absolute axonal sparing ${ }^{4}$. The inflammatory lesion develops in a multistep process initiated by transmigration of CNS antigen-specific autoreactive effector cells across the endothelial

Laboratory of Cellular Pathology, Department of Cellular \& Molecular Biology. Institute of Biology, Federal Fluminense University. Rio de Janeiro, Brazil: 'Department of Specialized Medicine, Rio de Janeiro University, ${ }^{2}$ Department of Neurology, Hospital Universitário Clementino Fraga Filho, Federal University of Rio de Janeiro, ${ }^{3} \mathrm{Hospital}$ da Lagoa and ${ }^{4}$ Department of Cellular \& Molecular Biology, Federal Fluminense University, Rio de Janeiro, Brazil. This study was supported by a grant number 522273/96-3 from the Brazilian National Council Research (CNPq).

Received 25 July 2000, received in final form 6 September 2000. Accepted 15 September 2000.

Dr. T Quirico-Santos - Laboratory of Cellular Pathology - Institute of Biology, UFF - Rua Visconde do Rio Branco - 24020-130 Niterói RJ Brasil. FAX 21719 5934.E-mail: tquirico@urbi.com.br 
blood brain barrier (BBB). Such events depend upon sequential expression of different families of ligands (adhesion molecules: ICAM, VCAM, PECAM) and corresponding receptors (e.g. integrins: LFA-1; CD11a/CD18) influenced by locally produced cytokines $^{5-7}$. A circulating soluble form of ICAM (sICAM-1) released mainly by CNS microvascular endothelial cells, has been detected in the serum of normal individuals ${ }^{8}$ although high levels have been associated with pathological conditions ${ }^{9-11}$. The sICAM-1 influence transendothelial migration of leukocyte across inflamed $B B B^{12}$ and thus may be a useful indicator of inflammatory disease and integrity of the $\mathrm{BBB}^{12,13}$.

Proinflammatory cytokines such as interferon gamma (IFN $\gamma$ ) and tumor necrosis factor (TNF $\alpha$ ) exert its activity through specific high-affinity receptors present in various cell types and modulate expression of cell adhesion molecules. Indeed constitutive adhesion molecules expressed or induced during active immune response, can be released from cerebral endothelial cell membranes following cytokine stimulation ${ }^{14,15}$. Moreover soluble TNF receptors (sTNF-R) capable of antagonize TNF action in vivo also up regulate TNF- $\alpha$ levels thus inducing TNF-associated activities ${ }^{10,11,17,18}$, such as cytotoxicity. Furthermore, the potential contribution of TNF $\alpha$ to tissue injury within the CNS ${ }^{2}$ is also dependent upon activation of CD95, a signaling receptor member of the TNF-R superfamily expressed on the target cells (e.g oligodendrocytes).

We therefore decided to determine with a high sensitive immunoassay, the levels of soluble ICAM-1 and TNF $\alpha R(60 \mathrm{kD})$ in sera and CSF samples of MS patients in an attempt to correlate with disease activity.

\section{METHOD}

\section{Subjects}

It were included 20 patients ( 16 female and 4 male) randomized by EpilNFO program ${ }^{19}$ with clinically definite MS according to Poser et al. ${ }^{20}$ criteria. The mean age was $40.05 \pm 11.28$ years old (range 15 to 59 ), the mean age of disease onset was $27.63 \pm 10.52$ years old (range 10 to 47). Relapsing-remitting (RR) course was defined ${ }^{20}$ either as very mild but sustained worsening or occurrence of clear episodes of disease over a short period (up to $48 \mathrm{~h}$ ) with full or partial recovery. Each patient attending neurological out-patient unit underwent full clinic-neurological examination and both T2-weighted and gadolinium-enhanced magnetic resonance imaging (MRI) of the brain and spinal cord. Seventeen patients (89.5\%) presented MRI imaging suggestive of myelinoclastic lesions. Determination of their disability was assessed by the same neuro- logist using the Kurtzke ${ }^{21}$ Expanded Disability Status Score (EDSS). The mean of the EDSS was $3.36 \pm 2.12$, and $63.2 \%$ patients presented EDSS 0.0 to $3.5,26.3 \%$ presented EDSS 4.0 to 6.0 , and $10.6 \%$ presented EDSS 7.0 to 8.0 . Selected patients had no clinical signs of concurrent infection. This study was approved by the Ethical Research Committee of the University Hospital and informed consent was obtained from each patient, including controls.

\section{Sample processing}

Blood and cerebrospinal fluid (CSF) samples were obtained from MS patients either at remission (stable) or relapse (active) phase of disease. CSF samples were collected from lumbar puncture before patients received immunosuppressive therapy. Control non-inflammatory CSF were obtained from 7 patients ( 3 females and 4 males) mean age of $46.1 \pm 8.93$ years (range 34 to 59 ) with intervertebral herniated disc (HD) undergoing myelography at the time of study. Control sera were collected from clinically healthy volunteers (6 males) with mean age of $48.7 \pm 9.05$ years (range 38 to 59 ). To prevent protein degradation, all samples were treated at the time of sample collection with a protease inhibitor $5 \mathrm{TIU} / \mathrm{ml}$ aprotinin (Sigma Chem.Co., USA), stored at $-70^{\circ} \mathrm{C}$ until and thawed just before testing to avoid loss of biological activity.

\section{Immunoassay for detection of}

\section{soluble ICAM-1 and TNFR (60kD)}

It was used in vitro CELLFREE ${ }^{\circledR}$ enzyme-linked immunosorbent assay (ELISA) for the quantitative measurement of human soluble ICAM-1 (CD54) and human soluble TNF Receptor (60kD) (sTNFR Type I) with system developed by Endogen, Inc. Wolburn, MA, USA. Duplicate samples from each patient, controls and standards were assayed the dilution recommended by the manufacturer. Absorbance readings were carried out in a BIORAD Model 3550 microplate reader at $450 \mathrm{~nm}$ or $490 \mathrm{~nm}$ and determined the interpolation of unknown values relative to the standard curves.

\section{Statistical analysis}

Data are reported as mean \pm standard deviation (SD). Student's t-test was used to compare CSF levels of sICAM1 or sTNF-R. Only values of $p$ less than 0.05 were considered significant. Non-parametrical analysis using the Spearman Rank Correlation Coefficient (SRCC) was employed to assess relationship between sICAM-1 levels and sTNF-R levels with clinical parameters.

\section{RESULTS}

\section{Clinical data}

Mean length of disease related to first symptoms was 131 months (range 12 to 336) with an average of 5.7 (range 1 to 19) relapses. At the moment of sample collection MS patients were considered in 
Table 1. Measurement of soluble adhesion molecule ICAM-1

\begin{tabular}{lccc}
\hline Groups & N & Serum $n g / m l$ & CSF $n g / m l$ \\
\hline Stable disease & 14 & $627 \pm 36.2$ & $215.0 \pm 26.6$ \\
Acute relapse & 6 & $657 \pm 124.9$ & $264.0 \pm 79.8$ \\
Control & $6-7$ & $276 \pm 87.3$ & $11.5 \pm 6.01$ \\
\hline
\end{tabular}

The results expressed in $\mathrm{ng} / \mathrm{ml}$ represent the mean value \pm SD of serum and CSF levels of soluble sICAM-1 (CD54) assayed by ELISA. Normal values were obtained from sera provided by six healthy subjects and CSF by seven patients with herniated disc.

clinical remission (stable phase) without showing subacute appearance of new symptoms or the significant worsening of existing symptoms for more than 24 hours in the absence of fever.

There was a straight correlation $(r=0.3894)$ of EDSS disability with length of disease and number of relapses. Those patients with onset still occurring during first decades of life (10 to 19 years) and with longer duration of disease (more than 180 months) had a poor course. Indeed, mean of relapses in this group was 14 \pm 2.6 (range 10-19) with evident degree of disability EDSS 7 (range 4 to 9). The patients with disease length varying from 12 up to 72 months usually had low EDSS score (range 1 to 3 ).

\section{Detection of CSF and serum soluble} adhesion molecule ICAM-1 (CD54)

Comparing to control groups, MS patients showed increased levels $(p<0.001)$ of sICAM-1 in both CSF and blood samples (Table 1). Control group formed by individuals without clinical and/or laboratory signs of inflammation had mean levels of slCAM-1 in the serum of $276 \pm 87.3 \mathrm{ng} / \mathrm{ml}$ (range 187 to $387 \mathrm{ng} / \mathrm{ml}$ ) considered in the normal range. In contrast, MS patients showed a marked increase of sICAM-1 in the serum: $639 \pm 194 \mathrm{ng} / \mathrm{ml}$ (range 322 to $1239 \mathrm{ng} / \mathrm{ml}$ ). Likewise, CSF levels of sICAM

Table 2. Measurement of soluble TNF-R1 (60 kd).

\begin{tabular}{lccc}
\hline Groups & $\mathrm{N}$ & Serum & CSF \\
\hline Stable disease & 14 & $14.9 \pm 1.56$ & $11.6 \pm 0.89$ \\
Acute relapse & 6 & $12.9 \pm 1.9$ & $10.9 \pm 1.30$ \\
Control & $6-7$ & $1.59 \pm 0.39$ & $1.28 \pm 0.65$ \\
\hline
\end{tabular}

The results are expressed as $\mathrm{ng} / \mathrm{ml}$. The results are expressed as the mean \pm SD of serum and CSF levels of STNFR- $\alpha$ measured using appropriated ELISA. Normal values of this molecules were obtained from sera provided by six healthy subjects and normal CSF by seven patients with intervertebral herniated disc. in MS patients were $230.5 \pm 29.8 \mathrm{ng} / \mathrm{ml}$ (range 104 to $533 \mathrm{ng} / \mathrm{ml})$ significantly higher $(p<0.001)$ than control group mean 11.05 (range 0 to $31.5 \mathrm{ng} / \mathrm{ml}$ ) formed by IHD patients. In addition it was also observed a clear correlation of increased serum levels of sICAM-1 with length of disease $(r=0.46343)$, EDSS $(r=0.31801)$ and relapses $(r=0.14538)$.

\section{Detection of CSF and serum}

soluble TNF-R1 (60kD)

Approximately a ten fold increase $(p<0.001)$ in the levels of sTNF-R in both serum $(14.2 \pm 1.20 \mathrm{ng} /$ $\mathrm{ml})$, range 8.66 to $22.2 \mathrm{ng} / \mathrm{ml}$, and CSF $(11.4 \pm 0.71$ $\mathrm{ng} / \mathrm{ml}$ ), range 8.90 to $18.8 \mathrm{ng} / \mathrm{ml}$, was consistently observed in MS patients. Regardless stage of disease and lack of a positive correlation with degree of disability as reflected by EDSS scores $(r=0.0032)$, length of disease $(r=0.0029)$ and number of relapses $(r=0.0096)$, MS patients showed consistently (Table 2) higher concentrations of soluble TNF-R1 in comparison to respective control sera (1.59 \pm 0.39 $\mathrm{ng} / \mathrm{ml})$ and $\operatorname{CSF}(1.28 \pm 0.62 \mathrm{ng} / \mathrm{ml})$,

\section{DISCUSSION}

Susceptibility to MS is genetically controlled, involving mainly gene related to auto-immune functions. These included MHC haplotypes, immunoglobulin, T cell receptor, cytokines (like TNF $\alpha$ ), and other candidate autoantigen ${ }^{22}$. In recent years, we have seen growing evidence for the role of cytokines in the pathogenesis of several infectious and noninfectious inflammatory CNS disease states, including MS. TNF $\alpha$ has been linked to inflammatory demyelination of MS and animal models of immunemediated CNS damage. Among cytokines and growth factors induced by brain damage, TNF $\alpha$ is well poised to modulate cellular injury as it is expressed more rapidly (peak protein level within 3 to 6 hours from acute injury) than other cytokines. It has been identified in MS brain lesions, and high 
concentrations have been reported in CSF and serum from MS patients. Moreover, CSF and systemic levels of TNF $\alpha$ in MS appears to reflect clinical disease activity, mediating oligodendrocyte damage through the inhibition of potassium channels, induction of apoptosis, and upregulation of adhesion molecules, especially ICAM-1 ${ }^{23}$. It was observed significantly increased levels of soluble ICAM-1 and soluble TNF $\alpha$ receptor in the CSF of 33 MS patients with acute relapsing MS during exacerbation and those with progressive disease when compared with 13 subjects with other neurological diseases ${ }^{11}$. CSF levels of sICAM-1 and STNF $\alpha$ were positively correlated in patients with acute relapsing MS during an exacerbation ${ }^{11}$. This is in light of previous evidence indicating that proinflammatory cytokines such as TNF $\alpha$ and adhesion molecules (sICAM-1) may represent markers of inflammation ${ }^{3,4,11}$.

This study sought to evaluate with a high sensitive immunoassay the profile of soluble ICAM- 1 and TNF-R1 in the serum and CSF samples in a population of Brazilian MS patients during active and stable phases of the disease. To the best of our knowledge this is the first report of a cytokine study and its correlation with clinical aspects of Brazilian MS patients.

In the present study, we found a close correlation of increased serum and CSF levels of sICAM-1 with length of disease, EDSS and number of relapses, but not with clinical course. Indeed, MS patients either in acute relapsing or remission showed increased levels of sICAM-1 in both serum and CSF. Moreover, MS patients with clinically active disease showed altered MRI and very high levels of soluble ICAM-1 in both serum and CSF. The evidence of increased serum levels of sICAM-1 during acute relapses are in accordance with recently reported data ${ }^{11,14,24-26}$ showing elevated expression of adhesion molecules (ICAM-1) on the luminal surface of endothelial cells in active MS lesions. In this sense, high concentrations of SICAM-1 and VCAM- 1 in the peripheral blood during active disease would reflect BBB damage and may further serve as an adhesion ligand during extravasation of activated leukocytes into the brain tissue ${ }^{24,27}$. Indeed the extent of ICAM1 activation may vary within different regions of the inflamed brain tissue which ultimately may account for the varying degrees of neurological defi$\mathrm{cit}^{2,4,28,29}$.

Comparing to control groups, we observed that regardless stage of disease, MS patients showed a ten fold increase of sTNF-R1 levels in the serum and CSF samples. Similarly, increased levels of soluble
TNF-R1 paralleled with circulating levels of sICAM-1 adhesion molecule. We also noticed that patients with clinical signs of active disease were those showing increased levels of circulating soluble adhesion molecules and sTNF-R1. Soluble forms of TNF $\alpha$ $\mathrm{R} 1$ seems to prolong the half-life of the cytokine by protecting the biological activity against proteolytic degradation ${ }^{2,6,7}$ and ultimately influencing neuroprotective or neurotoxic effects ${ }^{2}$ with consequent death or survival of oligodendrocytes and myelin damage.

The presence of TNF $\alpha$ in inflammatory demyelinating lesions and its concentration in the CSF indicate a critical role for this cytokine in the pathogenesis of $\mathrm{MS}^{2,26-29}$ specially concerning neurological impairment due to its myelinotoxic activity. A rise in TNF $\alpha$ production by blood mononuclear cells apparently precedes clinical exacerbations and is associated with active inflammatory lesions ${ }^{28}$. Indeed, the severity of the relapse, measured by the EDSS score, highly correlate to the TNF production $^{29,30}$. TNF- $\alpha$ up regulate expression of adhesion molecules on endothelial cells and leukocytes thus facilitating adherence and extravasation of leukocytes into the CNS to initiate local tissue damage ${ }^{14,30}$. The results reported herein indicate that regardless clinical course of disease (relapse or remission) MS patients showed a steady inflammatory process within the CNS microenvironment. In this sense, development of new therapeutic strategies should take into account that MS is a disease characterized by a relentless inflammatory reaction within the brain tissue.

Acknowledgments - We thank Dr. Charles M. Poser for thoughtful discussions and criticism and Monica Caetano for sample processing.

\section{REFERENCES}

1. Compston DAS, Kellar Wood H, Roberstson N, Sawcer S, Wood NW. Genes and susceptibility to multiple sclerosis. Acta Neurol Scand 1995;161(Suppl.):43-51

2. Pouly S, Antel JP. Multiple sclerosis and central nervous system demyelination. J Autoimmunity 2000;13:297-306

3. Amor S, Baker D, Layward L, McComarck K, vanNoort JM. Multiple Sclerosis: variations on a theme. Immunol Today 1997;18:368-371.

4. Hartung HP, Reiners K, Archelos JJ, et al. Circulating adhesion molecules and TNF receptor in multiple sclerosis: correlation with magnetic resonance imaging. Ann Neurol 1995;38:186-193.

5. Ewing C, Bernard CC. Insights into the aetiology and pathogenesis of multiple sclerosis. Immunol Cell Biol 1998;76:47-54.

6. Bö L, Peterson JW, Mrk S, et al. Distribution of immunoglobulin superfamily members ICAM-1,-2,-3 and $\beta 2$ integrin LFA-1 in multiple sclerosis lesions. J Neuropathol Exp Neurol 1996;55:1060-1072.

7. Muller WA, Randolph GJ. Migration of leukocytes across endothelium and beyond: molecules involved in the transmigration and fate of monocytes. J Leuk Biol 1999; 66:698-704.

8. Cannella B, Raine C. The adhesion molecule and cytokine profile of multiple sclerosis lesion. Ann Neurol 1995; 37: 424-435.

9. Owens T, Sriram S. The immunology of MS and its animal model, EAE. Neurol Clin 1995;13:51-73. 
10. Vora AJ, Kidd D, Miller DH, et al. Lymphocyte-endothelial cell interactions in multiple sclerosis: disease specificity and relationship to circulating tumor necrosis factor a and soluble adhesion molecules. Mult Scler 1997;3:171-179.

11. Tsukuda N, Matsuda M, Miyagi K, Yanagisawa N. Increased levels of circulating intercellular adhesion molecule (ICAM-1) and tumor necrosis factor receptor in the cerebrospinal fluid of patients with multiple sclerosis Neurology 1993;43:2679-2682.

12. Trojano M, Abolió C, Ruggieri M, et al. Soluble intercellular adhesion molecule-I (sICAM-1) in serum and cerebrospinal fluid of demyelinating diseases of the central and peripheral nervous system. Mult Scler 1998; 4:39-44.

13. Sharief MK, Noori MA, Ciardi M, Cirelli A, Thompson EJ. Increased levels of circulating ICAM-1 in serum and cerebrospinal fluid of patients with active multiple sclerosis: correlation with TNF-alpha and blood-brain barrier damage. J Neuroimmunol 1993; 43: 15-21.

14. Sacca R, Cuff CA, Ruddle NH. Mediators of Inflammation. Curr Op Immunol 1997;9:851-857.

15. Zhang GX, Baker CM, Kolson DL, Rostami AM. Chemokines and chemokine receptors in the pathogenesis of multiple sclerosis. Mult Scler 2000;6:3-13.

16. Monteyne P, Sindic CJM. Data on cytokine mRNA expression in CSF and peripheral blood mononuclear cells from MS patients as detected by PCR. Mult Scler 1998;4:143-146.

17. Huang $W-X$, Huang $P$, Link H, Hillert J. Cytokine analysis in multiple sclerosis by competitive RT-PCR: a decreased expression of TNF in chronic progression. Mult Scler 1999;5:342-348.

18. Rohowsky-Kochan C, Molinaro D, Cook SD. Cytokine secretion profile of myelin basic protein T cells in multiple sclerosis. Mult Scler 2000;6:69-77.

19. Coulombier D, Hathcock L, Fajan R. EpiInfo, a word processing database and statistics program for public health from center for dis- ease control (CDC, USA) and from World Health Organization. EpiInfo Executive Health information shell. Epi-Info 1.0. Geneva, 1994.

20. Poser CM, Paty DW, Scheinberg L, et al. New diagnostic criteria for multiple sclerosis: guidelines for research protocols. Ann Neurol 1983;13:227-231.

21. Kurtzke JF. Rating neurologic impairment in multiple sclerosis: an expanded disability status scale (EDSS). Neurology 1983;33:14441452.

22. Wekerle H. Immune pathogenesis of multiple sclerosis: brain autoimmune reactivity and its control by neuronal function. Mult Scler 1998;4:136-137.

23. Sharief MK. Cytokines in multiple sclerosis: pro-inflammation or pro-remyelination? Mult Scler 1998;4:169-173.

24. Navikas V, Link H. Cytokines and the pathogenesis of MS. J Neurosci Res 1996;45:322-333.

25. Hvas J, Mclean C, Justsen J, et al. Perivascular T cells express the proinflammatory chemokine RANTES mRNA in multiple sclerosis. Scand J Immunol 1997;46:195-203.

26. Link H. Cytokine storm in multiple sclerosis. Mult Scler 1998;4:12-15.

27. Whalen MJ, Carlos TM, Dixon CE, et al. Reduced brain edema after traumatic brain injury in mice deficient in P-selectin and intercellular adhesion molecule-1. J Leuk Biol 2000;67:160-168.

28. Beck J, Rondot $\mathrm{P}$, Catinot $\mathrm{L}$, et al. Increased production of interferon gamma and tumor necrosis factor precedes clinical manifestation in multiple sclerosis: do cytokines trigger off exacerbations? Acta Neurol Scand 1988;78:318-323.

29. Liu J, Marino MW, Wong G,et al. TNF is a potent anti-inflammatory cytokine in autoimmune-mediated demyelination. Nature Med 1998;4:78-83.

30. Chofflon M, Fellay B. Monitoring multiple sclerosis course and activity with TNF alpha. Mult Scler 1998;4,188-192. 